\title{
Efektivitas Supervisi Akademik Pengawas PAI dalam Membina Guru Agama SMP dan SMA di Kecamatan Ipuh Kabupaten Mukomuko
}

\author{
Nasrul Hendri \\ SMP 2 Ipuh Bengkulu. Indonesia \\ * e-mail: nashendri@gmail.com
}

\begin{abstract}
This study aims to determine the effectiveness of Islamic education supervisors in fostering junior high school and senior high school religion subject teachers, including academic supervision on (1) planning, (2) implementation, (3) follow-up, (4) blocking and inhibiting factors. This research used an evaluative research approach. Respondents in this study amounted to 9 people, consisting of 2 supervisors and 7 Islamic teachers. Participants in this study consist of 1 Islamic education supervisor for junior high school, 1 Islamic education supervisor for senior high school, 5 Islamic education teachers in junior high school, and 2 Islamic education teachers in senior high school. Data were collected using the method of observation, interviews and documentation. The results of data analysis showed that the level of effectiveness of Islamic education supervisors in fostering Islamic educators in junior and senior high school has a score of $67.46 \%$. It means less effective because supervisors do not master academic supervision techniques, rarely receive supervisory training, and take a long trip to teach between schools.
\end{abstract}

Keywords: sacademic supervision; Islamic education supervisor; Islamic educator development

\section{PENDAHULUAN}

Supervisor atau pengawas bidang studi agama islam diangkat oleh menteri atau pejabat yang ditunjuk oleh menteri sesuai dengan ketentuan peraturan perundangundangan. Menurut Permen RI nomor 2 tahun 2012 bahwa Bupati/wali kota dapat mengangkat pengawas PAI pada sekolah setelah mendapat persetujuan dari Kepala Kantor Wilayah Kementerian Agama.

Pengawas PAI yang ada saat ini merupakan guru Pegawai Negeri Sipil (PNS) dari mata pelajaran agama islam di sekolah umum. Mereka diangkat menjadi pengawas oleh pihak terkait. Mereka itu dianggap mampu dan layak memberikan pembinaan terhadap guru PAI, sekaligus mampu memberikan layanan kepada stakeholder pendidikan, baik secara individu maupun secara kelompok. Keputusan tersebut merupakan salah satu usaha untuk meningkatkan kualitas proses dan hasil pembelajaran yang dilakukan oleh guru. Maka dari itu supervisi akademik terhadap kinerja guru perlu dilakukan oleh pengawas.

Menurut Glickman, supervisi akademik merupakan serangkaian aktivitas dalam membantu guru untuk mengembangkan kemampuannya dalam mengelola proses belajar mengajar guna mencapai tujuan pembelajaran yang telah ditentukan (Aedi, 2014). Sedangkan menurut Arikunto supervisi akademik yaitu supervisi yang menitik beratkan pengamatan pada masa akademik yang langsung berada dalam lingkup kegiatan pembelajaran yang dilakukan oleh guru untuk membantu siswa ketika sedang dalam proses belajar (Hasanah \& Kristiawan, 2019). 
Kemampuan supervisor profesional diharapkan mampu mengatasi kesulitankesulitan guru dan mampu meningkatkan kualitas mengajar guru mulai dari perencanaan, pelaksanaan dan tindak lanjut dari pembelajaran itu sendiri (Humairoh, Supriyanto, \& Burhanuddin, 2016). Supervisi telah membuktikan mempunyai hubungan yang positif dengan kinerja dan profesionalitas guru (Meirisa \& Hadiyanto, 2019). Dengan demikian kemampuan supervisor harus di atas rata-rata kemampuan guru dalam penguasaan materi pelajaran, pengembangan kurikulum, penggunaan model dan metode pembelajaran, pemanfaatan media pembelajaran, teknik evaluasi hasil pembelajaran, dan kemampuan memecahkan masalah pembelajaran. Maka dari itu untuk memperoleh supervisor yang kemampuannya di atas rata-rata guru, maka pihak yang mengangkat seseorang menjadi supervisor tersebut harus diperhatikan prestasinya dalam pembelajaran. Dengan demikian ketika mereka menjadi pengawas senantiasa mengukir prestasi yang mengagumkan baik secara pribadi maupun secara kelembagaan (Abbas, 2018).

Berdasarkan observasi awal di kabupaten Mukomuko terutama di wilayah Unit Pelaksana Teknis Daerah Dinas Pendidikan dan Kebudayaan pengawas PAI dalam melaksanakan tugasnya masih banyak menghadapi kendala. Terutama hal-hal yang berkaitan dengan teknis pendidikan yang meliputi kurikulum, proses belajar mengajar, evaluasi, dan kegiatan ekstrakurikuler. Sehingga berpengaruh kepada kinerja guru dalam mentransformasikan nilai-nilai dan pengetahuan agama Islam terhadap peserta didik. Penelitian ini bertujuan untuk mengungkap efektivitas supervisi akademik pengawas PAI dalam membina guru agama tingkat SMP dan SMA di Kecamatan Ipuh Kabupaten Mukomuko.

\section{METODE}

Jenis penelitian ini adalah penelitian evaluatif yang memiliki prosedur tersendiri, dimana penelitian jenis ini menuntut persyaratan yang harus dipenuhi beberapa kriteria, tolak ukur, atau standar yang berguna sebagai pembanding bagi data atau informasi yang diperoleh atau yang disebut dengan pengukuran (Sambudi, 2017). Selanjutnya, berdasarkan hasil pengukuran tersebut diambil keputusan (decision making) sebagai hasil evaluasi yang bermanfaat untuk mengambil kebijakan (policy making) dalam rangka untuk perbaikan dan peningkatan mutu (quality improvement) pada masa yang akan datang. Responden penelitian ini adalah pengawas Pendidikan Agama Islam dan Guru Pendidikan Agama Islam Kabupaten Muko-muko. Teknik pengumpulan data penelitian ini adalah observasi, wawancara, dan dokumentasi. Untuk menjamin keabsahan data dan informasi yang akurat maka dalam mengumpulkan data melalui wawancara dan observasi menggunakan snowball sampling technique. Teknik analisis data yang digunakan analisis deskriptif evaluatif, yaitu dengan menganalisa data yang ada kemudian membandingkannya dengan kriteria yang telah peneliti tetapkan tentang efektivitas supervisi akademik pengawas melalui perencanaan supervisi akademik, pelaksanaan supervisi akademik, tindak lanjut supervisi akademik, faktor pendukung dan penghambat supervisi akademik.

\section{PEMBAHASAN}

Data efektivitas supervisi akademik oleh pengawas Pendidikan Agama Islam didapat berdasarkan studi lapangan yang telah dilakukan. Responden dalam penelitian ini adalah pengawas PAI dan guru PAI di SMP dan SMA se-Kecamatan Ipuh Kabupaten Mukomuko. Dengan rincian 2 orang pengawas PAI, 5 orang guru PAI tingkat SMP dan 2 orang guru guru PAI tingkat SMA. Dengan demikian jumlah responden keseluruhan dalam penelitian ini adalah 9 orang, selanjutnya mereka dijadikan sebagai sumber informasi untuk mendapatkan data penelitian.

Efektivitas pelaksanaan supervisi akademik oleh pengawas PAI terdiri dari tiga ruang lingkup supervisi akademik yaitu; supervisi akademik pada perencanaan, pada pelaksanaan, dan tindak lanjut. Distribusi hasil penelitian efektivitas supervisi akademik oleh pengawas PAI di SMP dan SMA seKecamatan Ipuh Kabupaten Mukomuko disajikan dalam tabel berikut: 
Tabel 1. Distribusi efektivitas supervisi akademik pengawas PAI tingkat SMP seKecamatan Ipuh

\begin{tabular}{|c|c|c|c|c|c|}
\hline \multirow[b]{2}{*}{ No } & \multirow[b]{2}{*}{ Variabel } & \multicolumn{2}{|c|}{ Sumber Data } & \multirow[b]{2}{*}{$\begin{array}{l}\text { Rata- } \\
\text { rata }\end{array}$} & \multirow{2}{*}{$\begin{array}{l}\text { Tingkat } \\
\text { Keefekti } \\
\text { fan }\end{array}$} \\
\hline & & $\begin{array}{l}\text { Penga } \\
\text { was }\end{array}$ & Guru & & \\
\hline 1 & $\begin{array}{l}\text { Perencanaan } \\
\text { Supervisi } \\
\text { Akademik }\end{array}$ & $\begin{array}{l}71,43 \\
\%\end{array}$ & $\begin{array}{l}55,00 \\
\%\end{array}$ & $\begin{array}{l}63,22 \\
\%\end{array}$ & $\begin{array}{l}\text { Kurang } \\
\text { efektif }\end{array}$ \\
\hline 2 & $\begin{array}{l}\text { Pelaksanaan } \\
\text { supervisi } \\
\text { akademik }\end{array}$ & $\begin{array}{l}78,57 \\
\%\end{array}$ & $\begin{array}{l}27,14 \\
\%\end{array}$ & $\begin{array}{l}52,86 \\
\%\end{array}$ & $\begin{array}{l}\text { Kurang } \\
\text { efektif }\end{array}$ \\
\hline 3 & $\begin{array}{l}\text { Tindak lanjut } \\
\text { supervisi } \\
\text { akademik }\end{array}$ & $\begin{array}{l}83,33 \\
\%\end{array}$ & $\begin{array}{l}56,00 \\
\%\end{array}$ & $\begin{array}{l}69,67 \\
\%\end{array}$ & $\begin{array}{l}\text { Kurang } \\
\text { efektif }\end{array}$ \\
\hline & Rata-rata & $\begin{array}{l}77,78 \\
\%\end{array}$ & $\begin{array}{l}46,05 \\
\%\end{array}$ & $\begin{array}{l}61,91 \\
\%\end{array}$ & \\
\hline
\end{tabular}

Berdasarkan tabel di atas, hasil penelitian menunjukkan bahwa supervisi akademik oleh pengawas PAI pada perencanaan pembelajaran termasuk dalam kategori kurang efektif $(63,22 \%)$. Supervisi akademik oleh pengawas PAI pada pelaksanaan pembelajaran termasuk dalam kategori kurang efektif $(52,86 \%)$. Serta supervisi akademik oleh pengawas PAI aspek tindak lanjut termasuk dalam kategori kurang efektif (69,67\%). Dengan demikian hasil analisis skor secara keseluruhan menunjukkan bahwa pelaksanaan supervisi akademik oleh pengawas PAI termasuk dalam kategori kurang efektif dengan persentase sebesar $(61,91 \%)$.

Sementara itu, distribusi hasil penelitian pelaksanaan supervisi akademik oleh pengawas PAI ditingkat SMA se-Kecamatan Ipuh Kabupaten Mukomuko disajikan dalam tabel berikut:

Tabel 2. Distribusi efektivitas supervisi akademik pengawas PAI tingkat SMA seKecamatan Ipuh

\begin{tabular}{|c|c|c|c|c|c|}
\hline \multirow[b]{2}{*}{ No } & \multirow[b]{2}{*}{ Variabel } & \multicolumn{2}{|c|}{ Sumber Data } & \multirow[b]{2}{*}{$\begin{array}{l}\text { Rata- } \\
\text { rata }\end{array}$} & \multirow{2}{*}{$\begin{array}{c}\text { Tingkat } \\
\text { Keefekti } \\
\text { fan }\end{array}$} \\
\hline & & $\begin{array}{c}\text { Penga } \\
\text { was }\end{array}$ & Guru & & \\
\hline 1 & $\begin{array}{l}\text { Perencanaan } \\
\text { Supervisi } \\
\text { Akademik }\end{array}$ & $\begin{array}{l}85,71 \\
\%\end{array}$ & $\begin{array}{l}62,50 \\
\%\end{array}$ & $\begin{array}{l}74,11 \\
\%\end{array}$ & Efektif \\
\hline 2 & $\begin{array}{l}\text { Pelaksanaan } \\
\text { supervisi } \\
\text { akademik }\end{array}$ & $\begin{array}{l}85,71 \\
\%\end{array}$ & $\begin{array}{l}60,71 \\
\%\end{array}$ & $\begin{array}{l}73,21 \\
\%\end{array}$ & Efektif \\
\hline 3 & $\begin{array}{l}\text { Tindak } \\
\text { lanjut } \\
\text { supervisi } \\
\text { akademik }\end{array}$ & $\begin{array}{l}83,33 \\
\%\end{array}$ & $\begin{array}{l}60,00 \\
\%\end{array}$ & $\begin{array}{l}71,67 \\
\%\end{array}$ & Efektif \\
\hline & Rata-rata & $\begin{array}{l}84,92 \\
\%\end{array}$ & $\begin{array}{l}61,07 \\
\%\end{array}$ & $\begin{array}{l}72,99 \\
\%\end{array}$ & \\
\hline
\end{tabular}

Berdasarkan tabel, hasil penelitian menunjukkan bahwa supervisi akademik oleh pengawas PAI pada perencanaan pembelajaran di SMA se-Kecamatan Ipuh termasuk dalam kategori efektif (74,11\%). Supervisi akademik oleh pengawas PAI pada pelaksanaan pembelajaran di SMA se-Kecamatan Ipuh termasuk dalam kategori efektif $(73,21 \%)$. Serta supervisi akademik oleh pengawas PAI pada aspek tindak lanjut di SMA seKecamatan Ipuh termasuk dalam kategori efektif $(71,67 \%)$.

Hasil analisis skor secara keseluruhan menunjukkan bahwa pelaksanaan supervisi akademik oleh pengawas PAI di SMA seKecamatan Ipuh termasuk dalam kategori efektif dengan persentase sebesar (72,99\%). Jika digabungkan data efektivitas supervisi akademik pengawas PAI tingkat SMP dan SMA dalam membina guru diperoleh data sebagai berikut:

Tabel 3. Distribusi Efektivitas Supervisi Akademik Pengawas PAI Tingkat SMP dan SMA se-Kecamatan Ipuh

\begin{tabular}{|c|c|c|c|c|c|}
\hline \multirow[b]{2}{*}{ No } & \multirow[b]{2}{*}{ Variabel } & \multicolumn{2}{|c|}{ Sumber Data } & \multirow[b]{2}{*}{$\begin{array}{l}\text { Rata- } \\
\text { rata }\end{array}$} & \multirow[b]{2}{*}{$\begin{array}{l}\text { Tingkat } \\
\text { Keefektifan }\end{array}$} \\
\hline & & $\begin{array}{l}\text { Penga } \\
\text { was }\end{array}$ & Guru & & \\
\hline 1 & $\begin{array}{l}\text { Perencanaan } \\
\text { Supervisi } \\
\text { Akademik }\end{array}$ & $\begin{array}{l}85,71 \\
\%\end{array}$ & $\begin{array}{l}62,50 \\
\%\end{array}$ & $\begin{array}{l}74,11 \\
\%\end{array}$ & $\begin{array}{l}\text { Kurang } \\
\text { efektif }\end{array}$ \\
\hline 2 & $\begin{array}{l}\text { Pelaksanaan } \\
\text { supervisi } \\
\text { akademik }\end{array}$ & $\begin{array}{l}85,71 \\
\%\end{array}$ & $\begin{array}{l}60,71 \\
\%\end{array}$ & $\begin{array}{l}73,21 \\
\%\end{array}$ & $\begin{array}{l}\text { Kurang } \\
\text { efektif }\end{array}$ \\
\hline 3 & $\begin{array}{l}\text { Tindak lanjut } \\
\text { supervisi } \\
\text { akademik }\end{array}$ & $\begin{array}{l}83,33 \\
\%\end{array}$ & $\begin{array}{l}60,00 \\
\%\end{array}$ & $\begin{array}{l}71,67 \\
\%\end{array}$ & efektif \\
\hline & Rata-rata & $\begin{array}{l}84,92 \\
\%\end{array}$ & $\begin{array}{l}61,07 \\
\%\end{array}$ & $\begin{array}{l}72,99 \\
\%\end{array}$ & $\begin{array}{l}\text { Kurang } \\
\text { efektif }\end{array}$ \\
\hline
\end{tabular}

Berdasarkan tabel di atas, hasil penelitian menunjukan bahwa supervisi akademik oleh pengawas PAI pada perencanaan pembelajaran tingkat SMP dan SMA se-Kecamatan Ipuh termasuk dalam kategori kurang efektif $(68,67 \%)$. Supervisi akademik oleh pengawas PAI pada pelaksanaan pembelajaran tingkat SMP dan SMA se-Kecamatan Ipuh termasuk dalam kategori kurang efektif $(63,04 \%)$. Serta supervisi akademik oleh pengawas PAI pada aspek tindak lanjut tingkat SMP dan SMA seKecamatan Ipuh termasuk dalam kategori efektif (70,67\%). Dengan demikian secara keseluruhan efektivitas supervisi akademik 
pengawas agama tingkat SMP dan SMA di kecamatan Ipuh dalam kategori kurang efektif dengan persentase sebesar $(67,46 \%)$.

Berdasarkan analisis data hasil penelitian, pelaksanaan supervisi akademik oleh pengawas PAI di SMP se-Kecamatan Ipuh Kabupaten Mukomuko termasuk dalam kategori kurang efektif (61,91\%). Hasil tersebut berdasarkan dari perolehan persentase tiga kegiatan supervisi akademik, yaitu supervisi akademik oleh pengawas PAI pada perencanaan pembelajaran masuk dalam kategori kurang efektif $(63,22 \%)$, supervisi akademik oleh pengawas PAI pada pelaksanaan pembelajaran masuk dalam kategori kurang efektif $(52,86 \%)$, dan supervisi akademik oleh pengawas PAI pada evaluasi pembelajaran masuk dalam kategori kurang efektif $(69,67 \%)$.

Sementara itu, pelaksanaan supervisi akademik oleh pengawas PAI di SMA seKecamatan Ipuh Kabupaten Mukomuko termasuk dalam kategori efektif (72,99\%). Hasil tersebut berdasarkan dari perolehan persentase tiga kegiatan supervisi akademik, yaitu supervisi akademik oleh pengawas PAI pada perencanaan pembelajaran masuk dalam kategori efektif $(74,11 \%)$, supervisi akademik oleh pengawas PAI pada pelaksanaan pembelajaran masuk dalam kategori efektif (73,21\%), dan supervisi akademik oleh pengawas PAI pada evaluasi pembelajaran masuk dalam kategori efektif $(71,67 \%)$.

Tiga kegiatan pengawas tersebut, yaitu pengawasan pada perencanaan, pelaksanaan dan penilaian pembelajaran merujuk kepada Peraturan Pemerintah (PP) nomor 19 tahun 2005. Pada PP tersebut, pasal 19 ayat 3 menyebutkan bahwa setiap tahun pendidikan melakukan perencanaan proses pembelajaran, pelaksanaan proses pembelajaran, penilaian hasil pembelajaran, dan pengawasan proses pembelajaran untuk terlaksananya proses pembelajaran yang efektif dan efisien (PP nomor 19 thaun 2005). Ayat ini secara eksplisit menyatakan bahwa pengawasan dilakukan untuk terlaksananya proses pembelajaran yang efektif dan efisien.

Terkait dengan hal itu, untuk melakukan tugas pengawasan tersebut, kompetensi supervisi akademik diatur oleh Peraturan Menteri Pendidikan Nasional Nomor 12 Tahun
2007 Tentang Standar Pengawas Sekolah/Madrasah meliputi: (a) memahami konsep, prinsip, teori dasar, karakteristik, dan kecenderungan perkembangan tiap mata pelajaran dalam rumpun mata pelajaran yang relevan di sekolah yang sejenis; (b) memahami konsep, prinsip, teori/teknologi, karakteristik, dan kecenderungan perkembangan proses pembelajaran/bimbingan tiap mata pelajaran dalam rumpun mata pelajaran yang relevan di sekolah yang sejenis; (c) membimbing guru dalam menyusun silabus tiap mata pelajaran dalam rumpun mata pelajaran yang relevan di sekolah menengah yang sejenis berdasarkan standar isi, standar kompetensi dan kompetensi dasar, dan prinsip-prinsip pengembangan KTSP; (d) Membimbing guru dalam memilih dan menggunakan strategi/metode/teknik pembelajaran/ bimbingan yang dapat mengembangkan berbagai potensi siswa melalui mata-mata pelajaran dalam rumpun mata pelajaran yang relevan di sekolah menengah yang sejenis; (e) membimbing guru dalam menyusun rencana pelaksanaan pembelajaran (RPP) untuk tiap mata pelajaran dalam rumpun mata pelajaran yang relevan di sekolah menengah yang sejenis; (f) membimbing guru dalam melaksanakan kegiatan pembelajaran/bimbingan (di kelas, laboratorium, dan atau di lapanga) untuk tiap mata pelajaran dalam rumpun mata pelajaran yang relevan di sekolah menengah yang sejenis; (g) membimbing guru dalam mengelola, merawat, mengembangkan dan menggunakan media pendidikan dan fasilitas pembelajaran/bimbingan tiap mata pelajaran dalam rumpun mata pelajaran yang relevan di sekolah menengah yang sejenis; dan (h) memotivasi guru untuk memenfaatkan teknologi informasi dalam pembelajaran/bimbingan tiap mata pelajaran dalam rumpun mata pelajaran yang relevan di sekolah menengah yang sejenis (Permen nomor 12 tahun 2007).

Namun, pengawas PAI sebelum melaksanakan tugas sebagai suvervisi akademik terlebih dahulu membuat perencanaan, melaksanakan dan kemudian menindaklanjuti tahap yang telah dilakukan. Hal ini dinyatakan dalam Permendiknas nomor 13 tahun 2007 tentang standar sebagai pengawas akademik melakukan 
perencanaan program supervisi akademik, (b) melaksanakan supervisi akademik terhadap guru dan (c) menindaklanjut hasil supervisi akademik untuk meningkatkan profesionalisme guru. Berdasarkan Permen nomor 13 tahun 2007 Profesionalisme guru tersebut mencakup kemampuan merencanakan, melaksanakan dan mengevaluasi pembelajaran.

Kegiatan supervisi akademik oleh pengawas PAI tidak melakukan bimbingan langsung kepada guru dalam merencanakan pembelajaran. Seharusnya pengawas berkewajiban membimbing guru dalam menyusun silabus dan Rencana Pelaksanaan Pembelajaran (RPP) untuk tiap mata pelajaran dalam rumpun mata pelajaran yang relevan di sekolah menengah yang sejenis. Selain itu, dijelaskan pula bahwa pengawas PAI harus membimbing guru dalam memilih dan menggunakan strategi/metode/teknik pembelajaran/ bimbingan yang dapat mengembangkan berbagai potensi siswa melalui mata-mata pelajaran dalam rumpun mata pelajaran yang relevan di sekolah.

Sedangkan menurut Nur Aedi dalam bukunya Pengawasan Pendidikan Tujuan Teori dan Praktek mengatakan bahwa pelaksanaan pengawasan akademik harus berlandaskan kepada prinsip demokratis (Aedi, 2014). Dimana supervisi akademik harus mampu menciptakan hubungan kemanusiaan yang harmonis sehingga dengan terjalinnya komunikasi yang baik maka pesan yang disampaikan dapat diterima dengan baik.

Menurut Purwanto disebutkan bahwa sebagai supervisor pengawas PAI berkewajiban membantu mengelola pembelajaran di kelas dan membantu guru dalam menilai proses pembelajaran yaitu bagaimana menggunakan teknik-teknik evaluasi dan pelaksanaan evaluasi itu sendiri. Dengan demikian, dalam kegiatan evaluasi pembelajaran pengawas PAI seharusnya membimbing guru dalam hal pembuatan soalsoal pembelajaran, penggunaan strategi dan metode penilaian, serta mengolah dan menganalisis hasil pembelajaran siswa supaya dapat mengukur dan melihat kemajuan belajar siswa (Anitsa, 2017).

Dalam Pedoman Pengawas Pendidikan Agama Islam pada Sekolah ditegaskan bahwa pengawas PAI pada sekolah mempunyai tugas untuk meningkatkan pemahaman kompetensi guru PAI, terutama kompetensi padagogik dan potensi profesionalisme (Tupoksi guru, Kompetensi guru, pemahaman kurikulum) dan meningkatkan kemampuan guru PAI dalam mengimplementasikan standar isi, standar proses, standar kompetensi kelulusan dan standar penilaian (pola pembelajaran, pengembangan silabus dan pengembangan RPP, pengembangan penilaian, pengembangan bahan ajar, dan penilaian butir soal). Dengan demikian pengawas harus melakukan pendampingan dan bimbingan untuk meningkatkan kemampuan guru sehingga dalam pelaksanaan pembelajaran tercipta suasana yang efektif dan efisien (Zulvah, 2015).

Hasil penelitian menunjukan bahwa supervisi akademik oleh pengawas PAI pada dimensi pelaksanaan ternyata tidak semua indikator ketersediaan ada dilakukan pengawas agama dalam melaksanakan supervisi akademik. Berikut tabel ketersediaan aspek dalam pelaksanaan pembelajaran disaat supervisi akademik terhadap guru PAI pada tingkat SMA di kecamatan Ipuh.

Kegiatan supervisi akademik oleh pengawas PAI dalam hal evaluasi pembelajaran dengan mengecek perangkat penilaian yang dipersiapkan guru, dianggap oleh para guru sebagai supervisi akademik yang kurang baik. Menurut Purwanto, disebutkan bahwa sebagai supervisor pengawas PAI berkewajiban membantu mengelola pembelajaran di kelas dan membantu guru dalam menilai proses pembelajaran yaitu bagaimana menggunakan teknik-teknik evaluasi dan pelaksanaan evaluasi itu sendiri (Anitsa, 2017). Dengan demikian pada tahap ini supervisor diharapkan memberikan masukan dan saran-saran kepada guru terhadap proses pembelajaran yang sudah dilakukan untuk perbaikan dan peningkatan kemampuan guru untuk proses pembelajaran selanjutnya.

Sedangkan menurut Daryanto dan Rachmawati, salah satu cara melaksanakan tindak lanjut hasil supervisi akademik adalah bila standar pembelajaran, pengetahuan, keterampilan dan sikap guru belum memenuhi standar, perlu dilakukan penilaian ulang (Aminah, 2016). Bila tujuannya belum tercapai 
juga maka supervisor merancang kembali program supervisi akademik untuk masa berikutnya. Dengan demikian pelaksanaan supervisi akademik harus mencapai standar pembelajaran, pengetahuan, keterampilan dan sikap guru. Jika hal itu belum tercapai maka pengawas harus mengambil tindakan dengan cara mengevaluasi program yang sudah dibuat.

Hasil supervisi harus ditindak lanjuti supaya memberikan dampak yang nyata bagi peningkatan profesional guru. Tindak lanjut itu seharusnya ada berupa penghargaan yang diberikan kepada guru yang telah memenuhi standar, dan teguran yang bersifat mendidik bagi guru yang belum memenuhi standar serta diberikan kesempatan untuk mengikuti pelatihan dan bimbingan agar profesional guru meningkat. Seorang supervisor setelah melaksanakan supervisi segera melakukan feedback untuk mengetahui tindak lanjut hasil supervisi yang sudah dilakukan. Permendikbud no. 65 tahun 2013, tindak lanjut supervisi yang sudah dilakukan hendaknya memberikan; a) penguatan dan penghargaan kepada guru yang menunjukan kinerja yang memenuhi atau melampai standar dan, b) pemberian kesempatan kepada guru untuk mengikuti program pengembangan keprofesionalan berkelanjutan (Novianti, 2015).

Berdasarkan hasil wawancara dengan pengawas PAI mengenai faktor pendukung dan penghambat pelaksanaan supervisi akademik, menunjukkan bahwa pengawas PAI di kecamatan Ipuh belum memuaskan. Hal ini disebabkan pengawas PAI yang ada saat ini baik tingkat SMP maupun SMA di Kecamatan Ipuh hanya 2 kali mengunjungi guru PAI dalam satu tahun ajaran, kemudian para pengawas ini tidak pernah mendapatkan pelatihan-pelatihan kepengawasan. Begitu juga latar belakang pendidikan mereka dari bukan kepengawasan. Situasi di atas berpengaruh pada kualitas kinerja para pengawas dalam melakukan supervisi akademik. Secara tidak langsung akan berpengaruh pada kualitas hasil pendidikan agama Islam terutama di kecamatan Ipuh

Selama ini, teknik yang digunakan oleh pengawas PAI se-Kecamatan Ipuh adalah teknik kunjungan dan observasi kelas. Teknik tersebut merupakan salah satu teknik yang dijelaskan oleh Mulyasa" 1) kunjungan dan
Observasi Kelas, yaitu kunjungan dan observasi kelas dilakukan dalam rangka mencari informasi mengenai bagaimana proses pembelajaran berlangsung di dalam kelas menyangkut hal-hal seperti bagaimana penggunaan metode mengajar, penggunaan alat atau media dalam pembelajaran, penguasaan guru di kelas dan hal lain yang bersangkut-paut dengan proses pembelajaran, yang selanjutnya hasil dari observasi tersebut akan dijadikan bahan pertimbangan dalam memotivasi, mengarahkan, membina, dan membimbing guru dalam peningkatan kualitas pembelajaran dan peningkatan prestasi relajar siswa; (b) pembicaraan individual, yaitu teknik melalui pembicaraan antara supervisor dengan supervisi dalam proses supervisi. Pembicaraan ini dapat dilakukan dengan didahului kunjungan dan observasi kelas atau tanpa didahului dengan kunjungan dan observasi kelas. Pembicaraan dapat terjadi karena inisiatif supervisor, atau permintaan supervisee jika ia memerlukan bantuan atau pemecahan suatu masalah; (c) diskusi kelompok, merupakan forum pertemuan yang melibatkan banyak orang untuk membicarakan sesuatu melaui tukar fikiran dan informasi dalam upaya memperbaiki proses dan hasil pembelajaran. Diskusi dapat dilakukan dalam skala besar seperti diskusi panel, lokakarya, workshop, dan lain sebagainya, juga dapat dilakukan dalam skala kecil seperti rapat guru, pertemuan guru mata pelajaran sejenis dan lain sebagainya; (d) demonstrasi mengajar, teknik ini dilakukan dengan mendatangkan guru yang baik dalam mengajar untuk disaksikan guru lainnya sehingga guru lainnya itu dapat mengambil pelajaran dan manfaat dari cara mengajar yang telah dilihatnya (Sholichah, 2019). Demonstrasi mengajar juga dapat dilakukan oleh supervisor itu sendiri sebagai contoh bagaimana sebaiknya cara mengajar yang tepat, setelah demonstrasi dilakukan hendaknya guru diberi kesempatan untuk menganalisis dari apa yang telah dilihatnya dengan merujuk pada berbagai inovasi modelmodel pembelajaran (Rahmi, Helsa, \& Azrul, 2018; Syafril, Eldarni, \& Rahmi, 2018; Yoserizal \& Rahmi, 2019); dan (e) perpustakaan profesional, teknik ini berkait langsung dengan peningkatan kualitas sumberdaya manusia, dalam hal ini guru, 
sehingga guru akan menjadi profesional, guru yang profesional harus selalu berusaha meningkatkan kualitas dirinya melalui kegiatan membaca buku-buku. Oleh karenanya perlu diwujudkan perpustakaan yang menyediakan buku-buku berkualitas yang penting dan menunjang pelaksanaan tugas guru.

\section{KESIMPULAN}

Berdasarkan hasil penelitian dan pembahasan di atas dapat disimpulkan bahwa tingkat efektivitas superpivisi akademik pengawas PAI dalam membina guru agama SMP dan SMA se Kecamatan Ipuh berada pada kategori kurang efektif karena diperoleh skor $67,46 \%$. Faktor pendukung supervisi akademik pengawas PAI dalam membina guru agama SMP dan SMA di Kecamatan Ipuh adalah sekolah dan guru selalu terbuka menerima kedatangan pengawas. Sedangkan faktor penghambat supervisi akademik disebabkan pengawas tidak menguasai teknikteknik supervisi akademik, jarang mendapatkan pelatihan kepengawasan, dan jarak tempuh yang jauh antar sekolah.

\section{REFERENSI}

Abbas, A. (2018). Implementasi Teknik Supervisi Akademik Dalam Meningkatkan Kualitas Pembelajaran. Didaktika: Jurnal Kependidikan, 12(1), 15-30.

https://doi.org/10.30863/didaktika.v12i1.1 73

Aedi, N. (2014). Manajemen Pendidik dan Tenaga Pendidikan. Yogyakarta: Gosyen Publishing.

Aminah, S. (2016). Pendekatan Efektif Supervisi Pembelajaran dalam Meningkatkan Profesionalisme Guru di Lembaga Pendidikan Islam. Jurnal Penjaminan Mutu, 2(1), 105. https://doi.org/10.25078/jpm.v2i1.67

Anitsa, Y. S. (2017). Supervisi Akademik Pengawas dalam Menigkatkan Kompetensi Pedagogik Guru PAI MI di Kecamatan Dukuhturi Tegal. Universitas Islam Negeri Walisongo.

Hasanah, M. L., \& Kristiawan, M. (2019).
Supervisi Akademik dan Bagaimana Kinerja Guru. Tadbir: Jurnal Studi Manajemen Pendidikan, 3(2), 97-112. https://doi.org/10.29240/jsmp.v3i2.1159

Humairoh, F., Supriyanto, A., \& Burhanuddin, B. (2016). Implementasi Supervisi Klinis dalam Meningkatkan Kualitas Pembelajaran Guru di Sekolah Dasar. Jurnal Pendidikan: Teori, Penelitian, Dan Pengembangan, 1(12), 2231-2235.

Meirisa, A., \& Hadiyanto. (2019). Pengaruh Pelaksanaan Supervisi Pendidikan Terhadap Kinerja Guru Di Sekolah Dasar, 20(1), $17-21$. https://doi.org/10.31227/osf.io/tqvzk

Novianti, H. (2015). Pelaksanaan Supervisi Akademik Kepala Sekolah dalam Meningkatkan Kinerja Guru. Jurnal Manajer Pendidikan, 9(2), 350-358.

Rahmi, U., Helsa, Y., \& Azrul, A. (2018). Integrating technology and media into mathematics learning. In The 6th South East Asia Design Research International Conference (6th SEA-DR IC) (Vol. 1088). https://doi.org/10.1088/17426596/1088/1/012073

Sambudi, S. (2017). Supervisi Akademik Kepala Sekolah dalam Meningkatkan Profesionalisme Guru Sertifikasi di SMAN 2 Mukomuko. Jurnal An-Nizom, 2(3), 589-600.

Sholichah, U. C. (2019). Penerapan Teknik Supervisi Kunjungan Kelas dalam Meningkatkan Profesionalisme Guru di Sekolah Kreatif SD Muhammadiyah 20 Surabaya. Jurnal Dinamika Manajemen Pendidikan, $\quad 1(2), \quad 141$. https://doi.org/10.26740/jdmp.v1n2.p141150

Syafril, S., Eldarni, E., \& Rahmi, U. (2018). Teknologi Pendidikan: Peningkatan Kualitas dan Akses Pendidikan. Jakarta: Prenada Media Group.

Yoserizal, Y., \& Rahmi, U. (2019). Perbedaan Aktivitas Belajar Siswa antara Model Cooperative Learning Tipe Snowball Throwing dengan Tipe Think Pair Share. Jurnal Basicedu, 3(2), 524-532. https://doi.org/10.31004/basicedu.v3i4.24 7

Zulvah, I. (2015). Kompetensi Pedagogik Guru Pendidikan Agama Islam Sekolah 
Menengah Atas. MUDARRISA: Journal

of Islamic Education, 9(1), 270.

https://doi.org/10.18326/mdr.v5i2.781 